\title{
Is Public Debt Management in Slovenia Efficient: An Empirical Analysis
}

Primož Dolenc*

\section{Abstract:}

Public debt management is one of basic fiscal functions the government performs. Public debt usually comprises a large share of nation's gross domestic product and is therefore an important instrument of fiscal policy. The purpose of this paper is to shed light on public debt management in Slovenia. Our goal was to estimate and present effects of debt management transactions performed by Slovenian Debt management office from year 2002 onwards. We found that these transactions had significant and positive effects on costs of public debt and also on its dynamics: they caused the turn in interest payments' trend and lowered the dynamics of upward-sloping trend of public debt.

Keywords: public debt, debt management, Slovenia

JEL: H63, G14

DOI: $10.2478 / v 10033-009-0012-5$

\section{Introduction}

Public debt management is one of basic fiscal functions the government performs. In fact, this issue has been pointed out numerous times in recent years as economies (and Slovenia as the last one) adopted Euro. Data shows that EU15 member states have a large debtto-GDP ratio - there are only few exemptions, but in all other countries this ratio exceeds $50 \%$ (see ECB (2004) and OECD (2003)). With public debt the government undoubtedly affects strongly financial markets, the market that has become so important in recent decades. And interest payments on public debt have risen to a significant share of public expenditures.

Governments have different goals in conducting public debt management policies which are often linked to public borrowing as such. Some are purely theoretical, but most debt management offices have their own very practical views on what the goal of public debt management is/should be. Wolswijk and de Haan (2005) see the most appropriate goals of public debt management in stabilization of the economy, development of financial market, support to monetary policy, and minimization of costs and risks caused or by connected with public debt. This is similar to what Tobin argued in early 60s (see Tobin, 1963), when he saw public debt as dramatically different to private one, naturally because of it's broader impacts. Barro (1999), Missale (1999) and other academics defend broader, macroeconomic, public etc. value of public debt, which therefore leads to a specific public debt management proposed practices.

The practical view on public debt and public debt management nowadays is less linked to theoretical discourse and more or less practically linked to concrete fiscal goals of public debt management. Kalderen (1997) as a primary goal of public debt management points out an efficient borrowing of the government; the primary goal therefore seems to be cost minimization of budget financing. In fact, the analysis of Carracedo and Dattels (1997) clearly shows that vast majority (86\%) of countries claim cost minimization as a primary goal of government debt management. Cassard and Folkerts-Landau (1997)

\footnotetext{
* Primož Dolenc

Faculty of management Koper

Cankarjeva 5, SI-6000 Koper

email: primoz.dolenc@fm-kp.si
} 
believe that in the past governments were more or less focused on short-term costs, while nowadays a longerterm perspective is relevant - long-term cost minimization, not only current cost minimization. Therefore the usual primary goal of public debt management today in many developed countries is purely the cost and risk minimization in correlation to public debt/past fiscal deficits.

Some secondary goals of public debt management do exist, of course. For developed economies Kladeren (1997) underlines two such goals. First, public debt management can help monetary policy to carry out monetary transactions more efficiently - monetary transmission mechanism is more efficient if the central bank caries out monetary policy operations via so-called "open-market-operations"; however, such operations are possible and efficient only on developed financial market, especially on developed market for government securities. Even though this goal widely is used in practice Townend (1997) finds that it is usually not exposed separately in majority of OECD countries. And secondly, public debt management can help develop broader financial market in the economy.

Public debt management is not a static term. On the contrary, the policy and practice of public debt management has been developing since first public debt and goes hand in hand with development of financial markets. Wolswijk and de Haan (2005) argue that a vast development of public debt management practices has been made when euro introduction and Maastricht criteria first became a serious issue. Then, after the introduction of euro after big-bang in 1999, when majority of exchange rate risk has been abolished, when market conventions have been introduced and when clearing systems have been interconnected, most public debt managers have boosted its "active debt management" role.

There are - however - countries where these "practical goals" are not (yet) primary goals of public debt management and where other broader goals (especially economic stabilization, financial market development etc.) are more emphasized. Transition countries, such as Slovenia, are such examples.

The main goal of this paper is to analyze the effect of debt management operations performed by Slovenian Ministry of finance (Debt management office) in 2002 and onwards. The year 2002 is taken as a base year because in 2002 some major debt management transactions were performed, while in preceding years more or less only standard primary market transactions were used. We can only speculate, whether or not these operations were strictly connected with the goal of early euro adoption; nevertheless, results were far beyond expected.

We test the following main hypothesis:

The introduction of active debt management in Slovenia in 2004 enhanced the efficiency of debt management and lowered the cost of government borrowing.

The paper is organized as follows. After introduction, a general overview on Slovenian debt and debt management is given in chapter 2. Chapter 3 discusses data and methodology used in our analysis. The last chapter before conclusion presents and discusses the empirical case.

\section{Public debt and debt management in Slovenia}

Slovenia went through several stages of public debt management since its transition to market economy in early 1990s. It started with extensive public debt originated in past Yugoslavia, which part it was until 1991. It has no public finances' deficit until 1997, but moved later on to moderate public finances' deficit. Since its inclusion in EU zone it coped with Maastricht criteria and in 2007 as a first transition country adopted euro.

Its independence has not started with "zero-balace", but with relatively large implicit and explicit inherited (public) debt. As implicit debt we mean the cost of urgent reform/sanitization/transition costs of banking sector and some major industries'. Until 1997 these "inherited costs" were the main drive of public debt in Slovenia. Later on, the majority of the increase of public debt was caused by budget deficit. Figure 1 shows the dynamics of public debt in Slovenia in recent years - absolute figures are divided regarding the background of the debt origin (sanitization vs. budget deficit).

\footnotetext{
${ }^{1}$ Two biggest Slovenian banks had to be capitalized, reconstructed and "pumped « with liquidity. It was done with public funds. These banks received a large amounts sovereign bonds that helped solve liquidity problems and enabled banks to get regular income from their prime sinvestments«.
} 


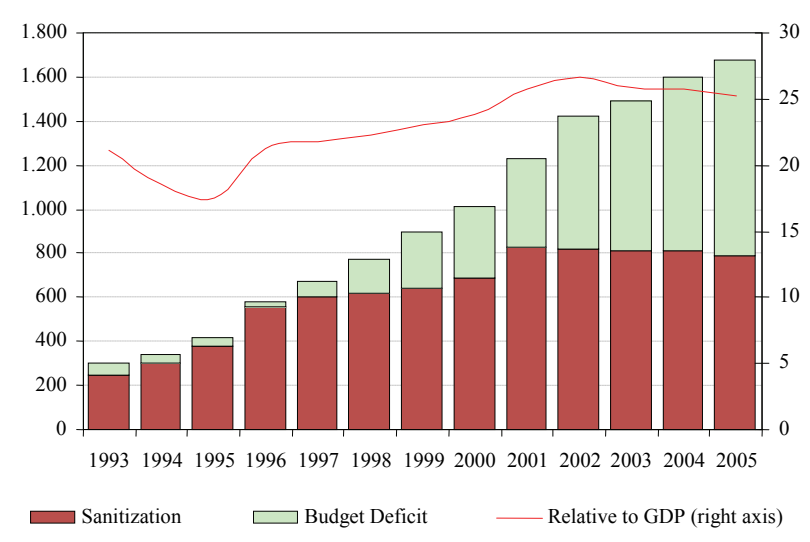

Figure 1: Public debt in Slovenia in the period from 1993 to 2005 in absolute terms (in bn SIT) and relative to GDP (in \%)

Source: Ministry of finance and own calculations

From public debt perspective, Maastricht criteria in Slovenia were never in question. However, since the independence, public debt has been growing in absolute and relative terms and so have costs of such debt. But until 2002 there were practically no real public debt management in place, while the only goal of Debt management office in Slovenia (which is a part of the Ministry of finance) was to ensure normal budget execution.

In 2002 some major shifts occurred: the goals and principles of debt management changed from passive to active, and some major debt management transactions were executed. Until 2001 the major goals of debt "management" were more or less theoretically focused on financial market development and budget financing, while in 2002 lowering public debt costs as one of the primary goals was stated explicitly. In 2002 Slovenian government sold a large share in largest Slovenian bank (Nova Ljubljanska banka), which enabled first debt management transactions - in the period from 2002 until 2005 the income from "privatization" was used to payback some old and expensive government securities in the total amount of SIT 110bn (i.e. $€ 460 \mathrm{mn}$ ). Besides cash operations also an innovative actions took place. With cash operations we mean operations where the government used the proceeds of the privatization for pay-off with cash the existing sovereign debt to debt holders. On the other hand, due to relatively low liquidity of Slovenian financial market at that period, that could be affected intensively by liquidity shock/over-liquidity in the still relatively closed financial market with some particularities in monetary policy, the decision of the government (harmonized with the central bank) was to try to avoid this over-liquidity. One solution was found: holders of old sovereign debt (with call option, but no call premium) were offered an exchange of debt - old-fornew at some premium. Several goals were achieved, e.g.: i) the effect on financial market was negligible, ii) the government lowered significantly the cost of borrowing, iii) even though some premium had to paid, the macroeconomic effect due to avoidance of liquidity shock and as a result of lower cost of new debt of the transaction was estimated as significantly positive on the basis of net present value (for more details see Dolenc 2006).

These debt management operations changed dramatically the structure of existing debt, while all major transition issues of government bonds were replaced with representative issues, issued at lower costs. These actions were followed also by secondary market development, which was lacking until 2002. Dolenc (2006) offers a more detailed insight in these transactions, while the purpose of this paper is merely to estimate longer term effects of such actions.

\section{Data and methodology}

The analysis is based on yearly data for the period from 1993 to 2005. We took three groups of data into consideration (as dependent variables):

a. interest payments on public debt,

b. interest payments on public debt with indexation cost ${ }^{2}$ and

c. amount of public debt at the end of the year.

With regards to the time horizon it has to be highlighted that one drawback of the analysis is without doubt the period after changes in debt management. Thus any conclusions have to be explained with caution. However, due to this drawback the methodology has been simplified to the level that still allows making relative firm conclusions.

To prove the hypothesis we considered to use linear trend analysis and test the significance of breaks in trend line. Therefore we formed time component $t(=1, \ldots, 13)$ for each year and two dummy variables $\left(D_{1}\right.$ and $\left.D_{2}\right)$ - one for each break ${ }^{3}$ :

\footnotetext{
2 Public debt in Slovenia was also linked to inflation or (prior to euro adoption) denominated in DEM, EUR or USD. According to methodology interest payments include only pure interest payments even though the real cost of debt include also payments of so-called indexation costs. ${ }^{3}$ Regarding the fact that budget deficit first occurred in 1997, the first expected break in trend line is in this year, whereas the second break tends to be after debt management operations were finished.
} 
$D_{1}=\left\{\begin{array}{lll}0 & ; & t<t_{1} \\ 1 & ; & t \geq t_{1}\end{array}\right.$

and

$D_{2}=\left\{\begin{array}{lll}0 & ; & t<t_{2} \\ 1 ; & t \geq t_{2}\end{array}\right.$.

For estimation the parameters of linear trend simple regression analysis was used. To test the significance of the break, the following trend line was estimated:

$$
T=\beta_{1}+\beta_{2} t+\beta_{3} V_{1}+\beta_{4} V_{2} \text {, }
$$

where:

$$
V_{1}= \begin{cases}0 \quad ; & t \leq t_{1} \\ \left(t-t_{1}\right) ; & t>t_{1}\end{cases}
$$

$$
V_{2}=\left\{\begin{array}{rl}
0 ; & t \leq t_{2} \\
\left(t-t_{2}\right) ; & t>t_{2}
\end{array} .\right.
$$

and

Parameter $t_{1}$ always denotes year 1997 , and $t_{2}$ tests the second brake if present.

Three analysis were performed, one for each dependent variable.

It is possible to speculate that some other factors affected 1) the level of interest rates in Slovenia, and 2) therefore also the level of public debt. The fact is, that interest rates have been constantly falling in Slovenia since the independence due to different reasons. Two are the most obvious. One is of course falling trend of inflation in Slovenia. Second is constantly improved credit rating of Slovenia ${ }^{4}$. However, these changes have been happening constantly without any major fall in any of the subsequent years, especially not from 2001 to 2002. Thus we speculate that any major shift in 2002 or 2003 might be attributable to the only major shift in one of many determinants of public debt - debt management policy.

\section{Results and discussion}

Figure 2 shows that interest payments on public debt in fact followed the trend we assumed. The trend of interest payments broke first in 1997, the first year of budget deficit in Slovenia. As shown in Table 1, until 1997 interest payments had been rising for SIT 3,3bn yearly, but later

\footnotetext{
${ }^{4}$ The credit risk for Slovenia, for example increased to AA- (S\&P) in June 2004 and then again to AA (S\&P) in May 2006).
}

on (until 2003) the slope became steeper and amounted SIT 9.5bn ${ }^{5}$ (in real prices as of 2002).

The analysis shows that after major debt management transactions in 2002, the upward-sloping trend for interest payments became downward-sloping. Results were not shown immediately, but after two years the interest payments became falling, even though public debt has still been rising.

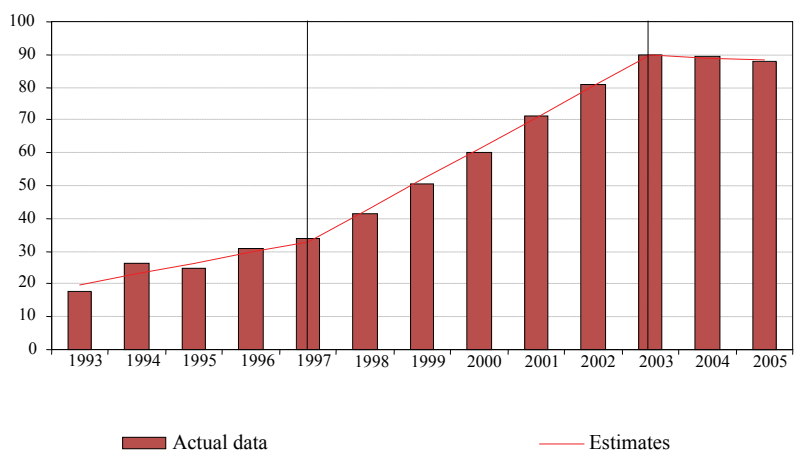

Figure 2: Actual and estimated interest payments on public debt in

\begin{tabular}{|c|c|c|c|c|c|c|}
\hline $\begin{array}{l}\frac{0}{0} \\
\frac{0}{\frac{0}{5}} \\
>\end{array}$ & 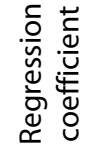 & 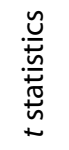 & $\begin{array}{l}\frac{a}{2} \\
\frac{2}{20} \\
e\end{array}$ & 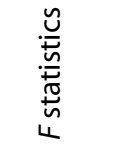 & 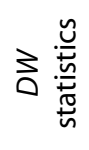 & $\approx$ \\
\hline constant & 16,46 & 9,92 & 0,00 & 1051,62 & 2,20 & 0,99 \\
\hline$t$ & 3,28 & 7,30 & 0,00 & & & \\
\hline$V_{1}$ & 6,21 & 9,50 & 0,00 & & & \\
\hline$V_{2}$ & $-10,23$ & 8,82 & 0,00 & & & \\
\hline
\end{tabular}
Slovenia in the period from 1993 to 2005 (in bn SIT)

Source: Ministry of finance and own calculations.

Table 1: Linear trend and trend's breaks estimation for interest payments

Source: own calculations.

Similar are the results for interest payments if we include also indexation costs: these costs began to fall. In fact, these costs of public debt became to fall already in 2002 and not in 2003 (as pure interest payment) - Figure 3 and Table 2. This "earlier effect" is in a way logical, because the debt management office repaid first debt with highest costs - and such debt was the inflation or foreign-exchange linked debt.

\footnotetext{
${ }^{5}$ Note that $€ 1$ amounted SIT 239.64 according to official exchange rate used for euro adoption in Slovenia.
} 


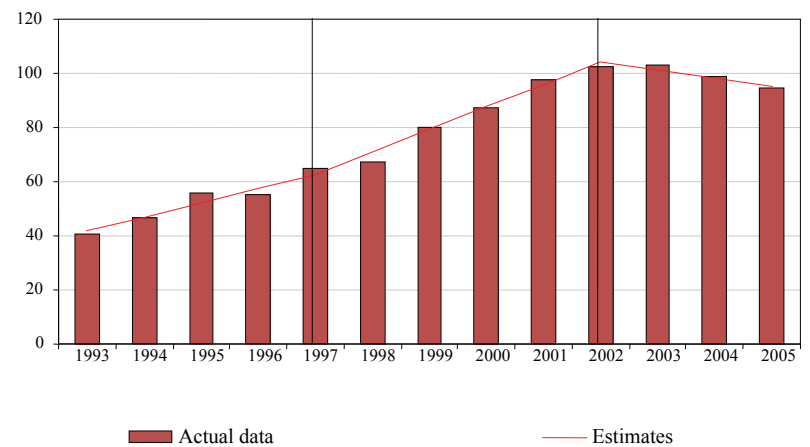

Figure 3: Actual and estimated interest payments on public debt (with indexation costs) in Slovenia in the period from 1993 to 2005 (in bn SIT) Source: Ministry of finance and own calculations.

\begin{tabular}{|c|c|c|c|c|c|c|}
\hline $\begin{array}{l}\frac{0}{0} \\
\frac{0}{\frac{0}{2}} \\
\frac{10}{7}\end{array}$ & 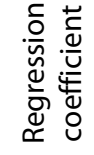 & 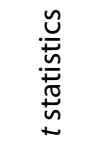 & $\begin{array}{l}\frac{0}{2} \\
\frac{\pi}{3} \\
0\end{array}$ & 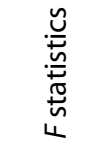 & 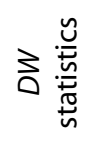 & $\approx$ \\
\hline constant & 36,40 & 15,63 & 0,00 & 369,86 & 2,00 & 0,99 \\
\hline$t$ & 5,22 & 8,16 & 0,00 & & & \\
\hline$V_{1}$ & 3,14 & 3,16 & 0,01 & & & \\
\hline$V_{2}$ & $-11,45$ & $-9,30$ & 0,00 & & & \\
\hline
\end{tabular}

Table 2: Linear trend and trend's breaks estimation for interest payments (with indexation costs)

Source: own calculations.

The results for public debt itself are also interesting. Even though on first sight there is no significant effect, statistical test proves a significant brake in year 2002 (Figure 4 and Table 3). The amount of public debt has not fallen due to debt management operation, though, but the dynamics of public debt became slower. Until 2002 the amount of public debt had been rising for almost SIT $150 \mathrm{bn}$ yearly, but after 2002 the yearly increase amounted on average only slightly more than SIT 100bn.

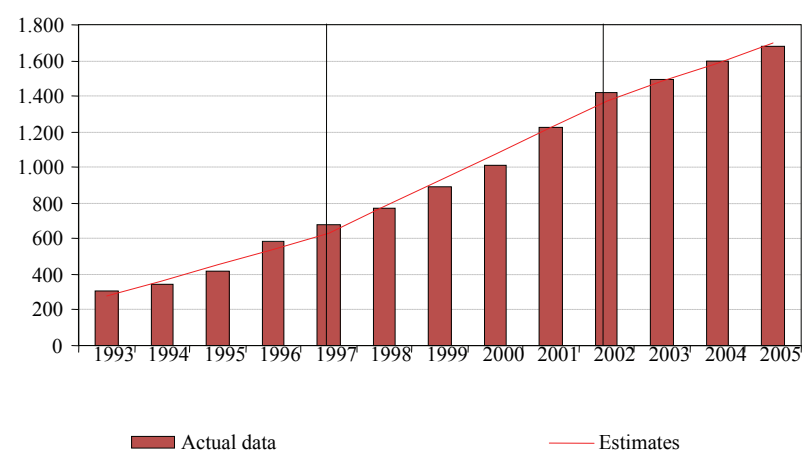

Figure 4: Actual and estimated amount of public debt in Slovenia in the period from 1993 to 2005 (in bn SIT)

Source: Ministry of finance and own calculations.

\begin{tabular}{|c|c|c|c|c|c|c|}
\hline$\frac{\frac{0}{0}}{\frac{0}{\frac{0}{2}}}$ & 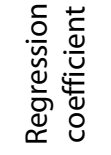 & 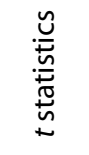 & $\begin{array}{l}\frac{0}{2} \\
\frac{\pi}{2} \\
2\end{array}$ & 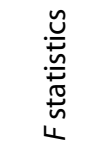 & 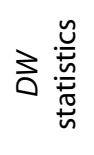 & $\approx$ \\
\hline constant & 190.72 & 4.92 & 0.00 & 637.02 & 2.46 & 0.99 \\
\hline$t$ & 87.54 & 8.23 & 0.00 & & & \\
\hline$V_{1}$ & 62.14 & 3.75 & 0.00 & & & \\
\hline$V_{2}$ & -43.96 & -2.15 & 0.06 & & & \\
\hline
\end{tabular}

Table 3: Linear trend and trend's breaks estimation for the amount of public debt

Source: own calculations

According to above analysis we can conclude that debt management operations, performed by Slovenian ministry of finance in year 2002 were successful as the cost of servicing public debt significantly decreased (in fact not only they decreased, but the trend curve shifted as well) and the dynamics of public debt decreased as well.

Further analysis can be focused on the effects of public debt management operations performed after Slovenia adopted euro in 2007. Some similar operations as in 2002 were accompanied with some drastic changes in primary and secondary market for government securities. But due to lack of "degrees of freedom" the analysis of recent developments were not yet possible, thus they remain for future research.

\section{Conclusion}

This paper tried to shed light on public debt management in the first transition EU member state that adopted euro in 2007. The goal was not to discuss theoretically possible debt management practices or go into details in debt management operations performed by Slovenian Debt management office; the goal to estimate and present effects of these transactions.

In the paper it is argued that debt management transactions, performed by Slovenian Debt management office from year 2002 onwards had significant and positive effects on costs of public debt and also on its dynamics. It was documented that debt management transactions broke the upward-sloping linear trend in interest payments on public debt (the turn was significantly proven in 2003 for pure interest payments and in 2002 for interest payments including indexation costs) and lowered the upward-sloping trend in the dynamics of public debt as such. 
For future research some additional analysis is left to be performed. Some major debt management operations and changes in microstructure of government securities market were performed as soon as Slovenia adopted euro. These changes were not taken into consideration in this analysis. Besides that after a while the analysis could include a longer time period that would enable to make even firmer conclusions. ㅁ.

\section{References}

Barro, R.J. 1999. Notes on Optimal Debt Management. Journal of Applied Economics 2(2), pp. 281-289.

Carracedo, M.F., and Dattels Peter, 1997. Survey of Public Debt Management Frameworks in Selected Countries. In Sundararajan V., P. Dattels, H.J. Blommestein H.J. (ed.). Coordinating Public Debt and Monetary Management. Washington D.C.: International Monetary Fund: 96-162.

Cassard, M., and D. Folkerts-Landau. 1997. Risk Management of Sovereign Assets and Liabilities. IMF Working Paper No. 166. Wachington D.C.: International Monetary Fund.

Dolenc, P. 2006. Public Assets and Debt Management. Doctoral Thesis. Ljubljana: Faculty of economics.

ECB. 2004. The Euro Bond Market Study. December 2004. Frankfurt: European Central Bank.

Kalderen, L. 1997. Debt Management Functions and Their Location. In Sundararajan V., P. Dattels, H.J. Blommestein H.J. (ed.). Coordinating Public Debt and Monetary Management. Washington D.C.: International Monetary Fund: 79-95.

Missale, A. 1999. Public Debt Management. Oxford: Oxford University Press.

OECD. 2003. Central Government Debt Statistical Yearbook. December 2003. Paris: Organization for Economic Co-operation and Development.

Tobin, J. 1963. An Essay on Principles of Debt Management. Fiscal and Debt Management Policies 6(1): 143-218.

Townend, J.. 1997. United Kingdom: Coordinaton Between Pubic Debt Management and Monetary Policy. In Sundararajan V., P. Dattels, H.J. Blommestein H.J. (ed.). Coordinating Public Debt and Monetary Management. Washington D.C.: International Monetary Fund: 301-311.

Wolswijk, G., J. De Haan. 2005. Goverment Debt Management in the Euro Area. Recent Developments and Changes in Practices. Occasional Paper Series No. 25. Frankfurt: European Central Bank. 